\title{
Information support for the procedure of providing land plots for investment projects
}

\author{
Dmitry Gura ${ }^{1 *}$, Nafset Khusht ${ }^{1}$, Olga Popova ${ }^{1,2}$, Ivan Markovsky ${ }^{1}$, Saida Pshidatok $^{3}$ \\ ${ }^{1}$ Kuban State Technological University, Moskovskaya str., 2, Krasnodar, 350072, Russia \\ ${ }^{2}$ Kuban State University, Stavropolskaya Street, 149, Krasnodar 350040, Russia \\ ${ }^{3}$ Kuban State Agrarian University named after I.T. Trubilin, Kalinina str., 13, Krasnodar, 350044, \\ Russia
}

\begin{abstract}
Nowadays, the problem of integrated and sustainable development of territories is especially acute in view of the fact that the process of urbanization is growing every year. A special role in implementing programs for improving the state of the urban environment and social spheres is played by investment projects, which are economic or social projects that are based on investments. At the same time, the implementation of most of these measures requires the assistance of state authorities or local self-government, which consists mainly in the provision of land for planned investment objects, for which a special order is used. This paper is devoted to issues related to the procedure for the provision of land plots for the implementation of investment projects in the territory of the constituent entity of the Russian Federation - Krasnodar Territory. The legal and regulatory framework governing the implementation of this procedure is analyzed, the existing information support offered to potential investors is considered. Conclusions are made about the main shortcomings of information support, a solution to the identified problem is proposed by creating an investment-oriented information system.
\end{abstract}

\section{Introduction}

In accordance with subparagraph 3 of paragraph 2 of Article 39.6 of the Land Code of the Russian Federation, there are cases of leasing a land plot without tendering in the case of leasing a land plot to legal entities in accordance with the order of a senior official of a constituent entity of the Russian Federation for the implementation of large-scale investment projects, subject to the compliance of these objects with criteria established by the laws of the constituent entities of the Russian Federation [3].

In relation to the Krasnodar Territory, the criteria necessary for making decisions on the implementation of an investment project in the Krasnodar Territory are regulated by the Law of the Krasnodar Territory dated March 4, 2015 No. 3123 - KZ "On the provision of legal entities with land plots that are in state ownership of the Krasnodar Territory or municipal property, or state property for which it is not delimited, for rent without tendering for the placement (implementation) of large-scale investment projects, objects of

${ }^{*}$ Corresponding author: gda-kuban@mail.ru 
socio-cultural and municipal purpose".

So, for investment projects to be implemented in the Krasnodar Territory, the following criteria are put forward, some of which are presented in [7].

The decision-making procedure on the compliance of a large-scale investment project with the Law of the Krasnodar Territory dated March 4, 2015 No. 3123-KZ, subject to which it is possible to provide land plots that are state-owned by the Krasnodar Territory or owned by the municipality, or state property for which it is not delimited, for rent without tendering, is approved by the Decree of the head of administration (governor) of the Krasnodar Territory of June 9, 2015 No. 522 [4, 6].

According to Article 3(2) of the Law of the Krasnodar Territory 3123-KZ, in case of confirmation of the fact that the investment project meets the above criteria regulated by the Law of the Krasnodar Territory dated March 4, 2015 No. 3123-KZ in compliance with the above procedure, an agreement is concluded on the implementation of a large-scale investment project between executive authority of the Krasnodar Territory, the head of administration (governor) of the Krasnodar Territory authorized by legal acts and the initiator of the project [4].

Based on the agreement, an order is prepared by the highest official of the constituent entity of the Russian Federation on the implementation of the approved investment project in the jurisdiction. In accordance with subparagraph 3 of paragraph 2 of Article 39.6 of the Land Code of the Russian Federation, the presence of this order will be confirmation of the basis for concluding a lease of land without tendering, to which the initiator of the investment project will refer when applying for the provision of the land.

Within ten days from the date of receipt of the application for the provision of the land, the authorized body generally returns this application to the project initiator if it does not meet the requirements established by law, is submitted to another authorized body or the documents that should be submitted in accordance with paragraph 2 of article 39.17 of the Land Code of the Russian Federation are not attached to the application. In this case, the authorized body must indicate the reasons for the return of the application for the provision of the land [3].

Within no more than thirty days from the date of receipt of the application for the provision of the land, the authorized body considers the application, checks for the presence or absence of the grounds provided for in Article 39.16 of the Land Code of the Russian Federation, and, based on the results of these reviews and checks, makes a positive decision, which consists in preparing a land lease agreement, or refuses to submit a land plot, indicating all reasons identified in accordance with article 39.16 of the Land Code of the Russian Federation Code [3].

\section{Methods and results}

An important factor in the implementation of large-scale investment projects is not only their compliance with the above criteria put forward by regulatory acts of the Krasnodar Territory, but also the interest of executive authorities in ensuring high-quality access of potential investors to a single database of free land plots owned by the Krasnodar Territory and proposed to involvement in the turnover, which, in turn, simplifies the selection of land plots that best meet the needs of investors, and the procedure for interaction between executive authorities and investor applicants at the stage of consideration of applications.

In this case, the main problem is the lack of a single concept for creating, maintaining, updating and presenting such a database, which can be implemented on a larger scale both in the form of a single information system and an Internet service based on a portal of services provided by executive authorities of the Krasnodar Territory.

It should also be taken into account that the fact that such land plots are in state 
ownership of the Krasnodar Territory may impose a number of restrictions on the availability of information on such land plots, which can be eliminated by considering the issue of payment for their provision and, thus, creating an additional source of income in the regional budget.

So, nowadays, a potential investor can access information about free land plots through the portal of the Department of Investments and Development of Small and Medium Enterprises on the tab "Investment proposals" presented in Figure 1 [5].

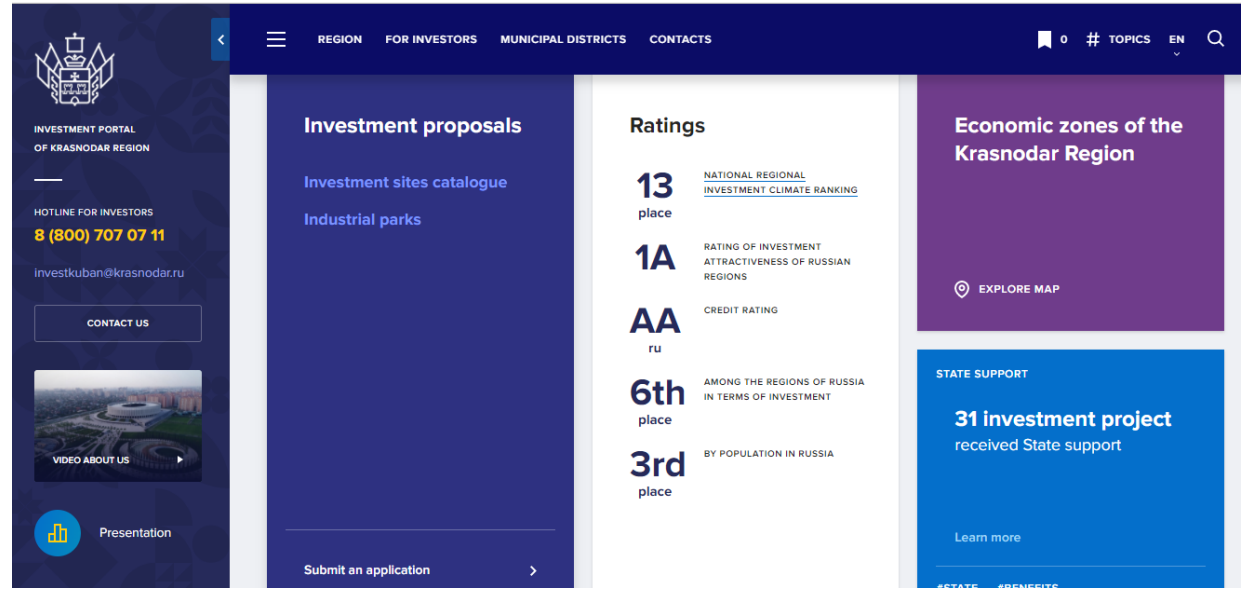

Fig. 1. Investment proposals

At the same time, general information about the investment sites offered to investors is divided into four sections, including a catalog of investment sites (see Fig. 2), Greenfield sites, Brownfield sites and industrial parks (see Figure 5).

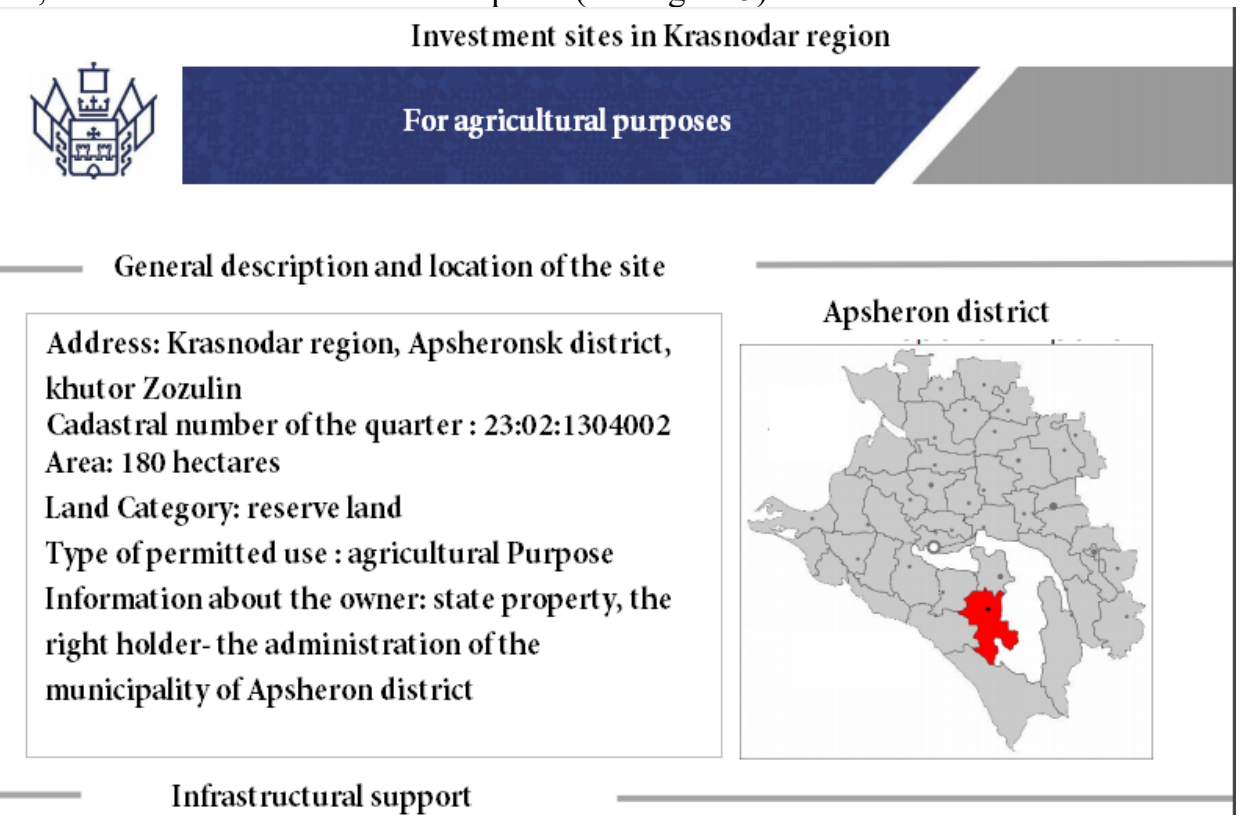

Fig. 2. Fragment of the catalog of investment sites

It is worth noting that the division of investment sites into two types - greenfield and 
brownfield - is carried out in the Krasnodar Territory in accordance with the classification system for industrial parks adopted abroad.

Moreover, the greenfield investment site means the territory intended for the implementation of the investment project "from scratch" on a new, previously undeveloped land, which in most cases also does not have a ready-made infrastructure.

The brownfield investment site is organized on the basis of a pre-existing production complex (on the territory of former factories, port plants, etc.).

Thus, information on sites such as Greenfield and Brownfield is presented on the information portal of the Department of Investment and Development of Small and Medium Enterprises in the form of Excel tables [5]. Information regarding industrial parks located in the Krasnodar Territory is presented by analogy with the catalog of investment sites (see Fig. 3).

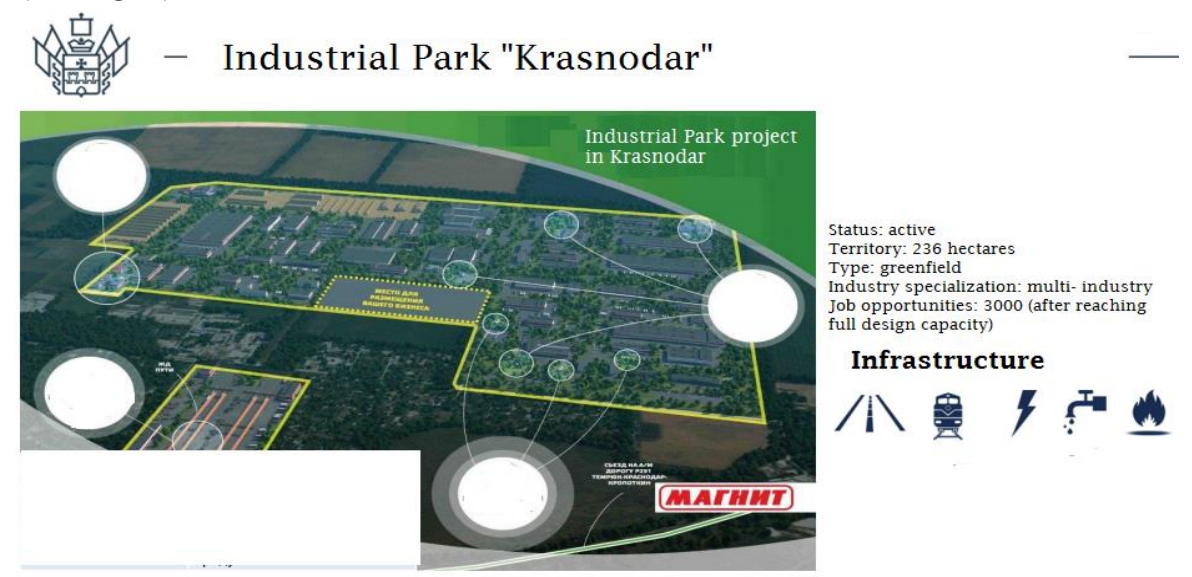

Fig. 3. Industrial parks of Krasnodar

\section{Analysis}

Analyzing the methods and format for presenting information on the areas proposed for development by attracting investors (land plots, land, greenfield and brownfield sites, industrial parks), it is worth highlighting a number of drawbacks presented in table 1 .

Table 1. Disadvantages of presenting information about investment objects to a potential investor

\begin{tabular}{|c|c|}
\hline te & $\begin{array}{l}\text { Disadvantages of presenting information about an investment } \\
\text { object to a potential investor }\end{array}$ \\
\hline $\begin{array}{l}\text { Land plots and } \\
\text { lands (catalog of } \\
\text { investment } \\
\text { sites) }\end{array}$ & $\begin{array}{l}\text { Lack of visual display of the location of communications suitable } \\
\text { for the land plot; } \\
\text { Lack of information on the location/absence within the boundaries } \\
\text { of land plots of zones with special conditions for the use of the } \\
\text { territory, cultural heritage objects and other objects that introduce } \\
\text { certain restrictions on the use of the land plot in accordance with its } \\
\text { type of permitted use. Moreover, there is also no information on the } \\
\text { selection parameters for such land plots when it is included in the } \\
\text { catalog of investment sites offered to the investor. } \\
\text { Lack of information on the cadastral value of the land to assess the } \\
\text { possibility for the investor of further redemption of the land/rental }\end{array}$ \\
\hline
\end{tabular}




\begin{tabular}{|l|l|}
\hline $\begin{array}{l}\text { Investment } \\
\text { object }\end{array}$ & $\begin{array}{l}\text { Disadvantages of presenting information about an investment } \\
\text { object to a potential investor }\end{array}$ \\
\hline $\begin{array}{l}\text { payments in the event of an investment agreement. } \\
\text { The difficulty of perceiving information by foreign investors. }\end{array}$ \\
\hline Brownfield sites & $\begin{array}{l}\text { Lack of visual display of the location, infrastructure, transport and } \\
\text { communication support of sites; } \\
\text { The difficulty of perceiving the information presented in the format } \\
\text { of Excel tables regarding the main characteristics of the land for } \\
\text { users who do not have special knowledge in the field of land } \\
\text { relations and land management, especially for foreign users. }\end{array}$ \\
\hline \multirow{7}{*}{ Industrial parks } & $\begin{array}{l}\text { Lack of visual display of the location of utility networks near the } \\
\text { land plot; } \\
\text { Lack of information on the location/absence within the boundaries } \\
\text { of land plots of zones with special conditions for the use of the } \\
\text { territory, cultural heritage objects and other objects that introduce } \\
\text { certain restrictions on the use of the land plot in accordance with its } \\
\text { type of permitted use. Moreover, there is also no information on the } \\
\text { selection parameters for such land plots when it is included in the } \\
\text { catalog of investment sites offered to the investor. } \\
\text { The difficulty of perceiving information by foreign investors. }\end{array}$ \\
\hline
\end{tabular}

By solving the problem of the lack of adequate information support for the implementation of investment projects in the Krasnodar Territory, the creation of a common investment-oriented information system will allow investors to receive all the necessary information to decide on the feasibility of investing in the implementation of a particular investment project. The general scheme of the system is presented in table 2 .

Table 2. Elements of a designed investment-oriented system

\begin{tabular}{|c|c|}
\hline $\begin{array}{l}\text { System } \\
\text { elements }\end{array}$ & Content \\
\hline $\begin{array}{l}\text { Input } \\
\text { information }\end{array}$ & $\begin{array}{l}\text { Information about lands and land plots (including information about } \\
\text { industrial parks, Greenfield and Brownfield sites) proposed for the } \\
\text { implementation of investment objects: } \\
\text { - Cadastral number (cadastral quarter number); } \\
\text { - Area; } \\
\text { - Cadastral value; } \\
\text { Information on the location of the land plot relative to the } \\
\text { boundaries of specially protected natural territories, zones } \\
\text { with special conditions for the use of the territory, cultural } \\
\text { heritage sites; } \\
\text { Data from Information System Designed for City Planning } \\
\text { (location of a land plot in a particular functional, territorial } \\
\text { zone, information on the presence/absence of approved } \\
\text { documentation for the planning of the territory, etc.); } \\
\text { Information on the presence/absence of objects of federal, } \\
\text { regional, local significance within the boundaries of the }\end{array}$ \\
\hline
\end{tabular}




\begin{tabular}{|c|c|}
\hline & $\begin{array}{l}\text { land plot. } \\
\text { - Coordinates of the boundaries of the land plot; } \\
\text { - Cartographic material (cartographic substrate, drawings, } \\
\text { graphic display of the location and boundaries of the land); } \\
\text { - Photo - material; } \\
\text { - Results of verification of the actual condition and use of } \\
\text { the land; } \\
\text { - Scanned model of the land; } \\
\text { - Information on the presence/absence of encumbrances; } \\
\text { Information about the availability and location of the necessary } \\
\text { service infrastructure (electricity; gas; water supply, etc.), as well as } \\
\text { the availability of nearby transport infrastructure. }\end{array}$ \\
\hline $\begin{array}{l}\text { Information } \\
\text { system }\end{array}$ & $\begin{array}{l}\text { Database } \\
\text { Cartographic background } \\
\text { Advanced search and selection of necessary information }\end{array}$ \\
\hline $\begin{array}{l}\text { Output } \\
\text { information }\end{array}$ & Comprehensive information about the land plot \\
\hline
\end{tabular}

\section{Discussion}

It should be noted that when building an information system, it is necessary to be guided by the following fundamental principles of creating information systems:

- the principle of systematicity, which implies taking into account all the interconnections between the individual subsystems and the role of each component in the functioning of a single system;

- the principle of development (openness), which allows updating information and data without violating the integrity and general operation of the information system;

- the principle of compatibility, which consists in the development of user interfaces for interaction with other systems and end users;

- the principle of standardization (unification), which takes into account the use of standard, standardized and unified elements when creating a system;

- the principle of effectiveness.

The relationship between the information system and subsystems is shown in Figure 6.

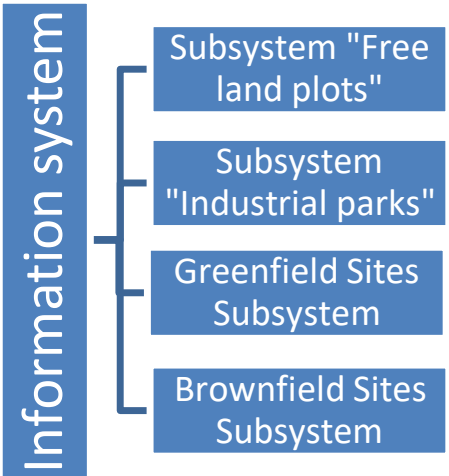

Fig. 6. Subsystems of an investment-oriented information system

It should also be additionally pointed out that in order to comply with the principle of 
development (openness) of the information system, the process of updating the information contained in the information system should be carried out on the basis of interagency interaction of all government agencies that have information directly relating to individual characteristics of investment sites in order to obtain the most complete picture of the possibility of implementing an investment project on a specific land plot.

\section{Conclusions}

The creation of an investment-oriented information system designed to interact with potential investors by providing the most complete reference information for each of the investment sites offered by the constituent entity of the Russian Federation, the Krasnodar Territory, will optimize the process of attracting investment funds to regional programs by eliminating the problem of information support for concluded agreements and taking into account all the characteristics and features regarding land offered for the development, support and creation of industrial and other enterprises.

\section{References}

1. F. Fiordelisia, L. Renneboogb et al., Journal of International Financial Markets, Institutions and Money 63, 101137 (2019)

2. W. Han, S. Zhao, X. Feng, L. Chen, Int. J. of Appl. Earth Observ. and Geoinform., 30, 56-64 (2014)

3. The Land Code of the Russian Federation of October 25, 2001 N 136-FZ (as amended on December 27, 2019)

4. The Law of the Krasnodar Territory dated March 4, 2015 No. 3123 - KZ

5. Investment portal of the Krasnodar Territory. Access mode: https://investkuban.ru/

6. Resolution of the head of administration (governor) of the Krasnodar Territory of June 9, 2015 No. 522 on approval of the Decision-making procedure on the compliance of a large-scale investment project, an object of socio-cultural and municipal purpose with the criteria established by the Law of the Krasnodar Territory of March 4, 2015 No. 3123-KZ

7. D.V. Kozlov Matters of Russian and International Law, 1(1B), (2017)

8. Y. Wanga, H. Oliver Gao, J. Liu. Transportation Research Part A: Policy and Practice, 125, Pages 20-34 (2019)

9. J. Liu, J. Liu, N. Liu. Physica A: Statistical Mechanics and its Applications, 123617 (2019)

10. S. Salm. Renewable and Sustainable Energy Reviews. 82(1), 1364-1375 (2018)

11. L. Zhi, X. Zhou. Procedia - Social and Behavioral Sciences. 96, 1050-1054 (2013)

12. Ö. Armaneria, G. Özdağoğlub, Ö. Yalçınkayaa. Journal of Computational and Applied Mathematics. 234 (8), 2530-2542 (2010)

13. M. Murzyn-Kupisz. Journal of Cultural Heritage, 14(2), 156-162 (2013)

14. E. Errais, J. Sadowsky. Computers \& Operations Research, 35(1), 90-112 (2008)

15. Y. Yang, G. Bi, L. Liu. European Journal of Operational Research, 280(11), 323-337 (2020) 